\title{
The Impact of Options Trading on the Relationship between Research Quotient and Firm Performance
}

\author{
Han-Ching Huang ${ }^{1}$, \& Calista Amelia Irawan ${ }^{2}$ \\ ${ }^{1}$ Department of Finance, Chung Yuan Christian University, Chung Li, Taiwan \\ ${ }^{2}$ International Master of Business and Administration, Chung Yuan Christian University, Chung Li, Taiwan \\ Correspondence: Han-Ching Huang, Department of Finance, Chung Yuan Christian University, Chung Li, \\ Taiwan. Tel: 886-3265-5710. E-mail: samprass@cycu.edu.tw
}

Received: April 9, 2017

Accepted: May 8, 2017

Online Published: May 15, 2017

doi:10.5539/ijef.v9n6p141

URL: https://doi.org/10.5539/ijef.v9n6p141

\begin{abstract}
The performance of innovation could be counted by the number of patent. Patent information enables a firm to estimate R\&D efficiency and stock market value. Nonetheless, patents is not universal because more than $50 \%$ companies in COMPUSTAT do not patent their new products. Since patents have some drawbacks, Cooper, Knott, and Yang (2015) use Research Quotient (RQ) as an indicator of firm innovation because RQ measures the productivity of the R\&D department, which produces a new innovative product and transforms it into revenues. In this paper, we examine the impact of option trading on the relation between RQ and stock market return (or firm value). We find that RQ has the positive impact on firm value, proxy by market-to-book (MTB) value. The option dummy, which is the firm with option trading, has significantly positive impact on the relation between RQ and firm value and insignificantly positive impact on the relation between RQ and future stock return. Nonetheless, interaction term of RQ and option volume has positive and significant impacts on MTB and future stock return.
\end{abstract}

Keywords: research quotient, firm value, stock return, option trading

\section{Introduction}

Market competition is getting stronger since product life cycles get shorter. This condition induces a firm to generate a series of innovations in yielding profitability to a firm and in persisting their competitive advantage over their competitors (Artz, Norman, Hatfield, \& Cardinal, 2010). Innovation is one of the drivers of economic growth of one firm, which can improve market share by producing new products to increase competitive advantage (Sood \& Telllis, 2009). However, to commit to research-based innovation, a firm must allocate some budget for R\&D spending, which is calculated as incurred expense (Lev \& Zarowin, 1999). Since research may have negative effect on earnings in short term period, some managers are unwilling to invest in R\&D. There is an uncertain time lag between initial research spending and product revenue, which could result in unprofitability for that firm (MacKenzie, 2005)

According to van der Eerden and Saelens (1991), patents have traditionally been associated with innovation and performance of countries and firms. By identifying the technology domains and industries in patent data, we can analyze the technological position of a firm or country relative to other countries and firms. Patents can be defined as indicators of important technology positions and innovative activity, which can help policy makers and analysts to measure weak and strong areas in national or regional (or firm) innovation systems. Another function of patent information is enabling a firm to estimate other characteristics, such as R\&D efficiency and stock market value (Hirshleifer, Hsu, \& Li, 2013). Hence, market uses the number of patents controlled by a firm as an indicator to value a firm's intangible assets.

The patents grant is associated with a greater probability of future profit stream because patent grants are usually marked off as precursor of potential new products in the future. However, the marketability of a patent is still uncertain. Usually, the patents grants do not produce future profitable products, and they just bring a small effect on market value. Nonetheless, the patent system has information to indicate which patents are more likely to generate future profits (Patel \& Ward, 2011). Related to patent importance, Trajtenberg (1990) and Hall, Jaffe, and Trajtenberg (2005) have explored citations to a patent as sign of the profitability of the invention. Citations 
could be a measure of patent value (Patel \& Ward, 2011). Thus, patents and citations are measures of innovative output. Moreover, Hirshleifer et al. (2013) document that the approved patent is usually a way to officially introduce the innovations to the public.

Although prior literature usually uses patent to measure innovation of firms, patent as an indicator has some drawbacks. They are not universal, since more than 50\% of companies in COMPUSTAT don't patent their new products (Cooper, Knott, \& Yang, 2015). However, it does not mean that firms that do not patent their products are not innovating. Firms decide not to patent their product for different reasons; for instance, to file and defense for patents requires high cost, and patents also expose the innovative products in the risk of being copied by other parties. To overcome the unreliability of patent as an innovation indicator, there is another way of measuring firm innovation, called Research Quotient (RQ). RQ may explain the optimal budget for research because RQ is defined as the ability of firm to generate revenues from its budget that is allocated for R\&D investment (Cooper et al., 2015). Using RQ as an indicator of firm innovation is better than other indicators because RQ measures the productivity of R\&D department. That is, RQ can describe how much fund a firm allocated for R\&D department to exploit their capabilities to produce a new innovative product that can be the firm's competitive advantage and be transformed into revenues.

Previous studies have discussed the impact of firm innovation on stock market return or firm value. They explain the innovation in association with number of patents or patents citation. RQ can help a firm decide the effectiveness of $R \& D$ investment relative to the other investments and observe how $R \& D$ expenditure can affect a firm's market value. Cooper et al. (2015) use RQ to investigate the impact of firm innovation on firm's stock market returns and its firm market value.

One type of financial derivatives is options. It has been used by many investors because of its high leverage compared to other type of assets. Some advantages of option are brokerage charge for taking position in option is lower than the charge in stock. Moreover, option could provide built-in downside protection for investors. The most common reason for investors to trade in option is option market provides strategic flexibility to informed traders because they could trade contracts on the same underlying security but with different exercise prices and maturities (Kaul, Nimalendran \& Zhang, 2004).

The active options market encourage market participants to gather private information about long-term investments, which results in more efficient stock prices (Cao, 1999; Chakravarty, Gulen, \& Mayhew, 2004; Hu, 2014; Pan \& Poteshman, 2006). Thus, option could decrease the asymmetric information problems about R\&D. Options trading leads to better monitoring by enhancing informational efficiency, which encourage firms to invest in innovation (Blanco \& Wehrheim, 2017). Although option trading can improve the quantity of innovation, we examine whether option trading can improve the quality of innovation by investigating the relation between RQ and firm value (or future stock return).

Cooper et al. (2015) investigate the feasibility of adopting RQ as a better way of measuring innovation to predict firm value and future stock return. Further, we examine the impact of option trading on the relation between RQ and stock market return (or market value).

The findings are as follows. First, we find that firm innovation, in term of RQ, have positive and significant impact on firm value, as measured by MTB. Thus, higher RQ is associated with higher MTB. Nonetheless, the impact of RQ on MTB with option dummy is lower than that without option trading. Once we change the option dummy into option volume, we find that more option volume is accompanied with higher impact of RQ on the firm value. We also investigate the effect of RQ on future stock return, which is taken one or two years after RQ takes place. Setting the option dummy factor into the model, we find that the impact of option dummy on the relation between future stock return and RQ is positive and insignificant. Nevertheless, an increase of option volume traded makes a increase on future stock return.

The remainders of this paper are organized as follows. Section 2 describes hypotheses, section 3 describes methodology and data. Section 4 shows empirical results, and Section 5 provides concludes, as well as limitations and suggestions.

\section{Hypotheses}

Options as one type of financial derivatives have been used by many investors owing to its high leverage. Brokerage charge for taking position in option is lower than the charge in stock. In addition, option could give built-in downside protection for investors. The above advantages may attract informed traders to participate in the option market (Chakravarty, Gulen, \& Mayhew, 2004; John, Koticha, Narayanan, \& Subrahmanyam, 2003; Mayhew, Sarin, \& Shastri, 1995). Mayhew et al. (1995) find that the decrease in margin is assumed as an 
increase in spreads and trade informativeness, and the decrease in depth for the underlying stocks. A change in option spreads denotes a change in the relative allocation of informed traders between the two markets. The information about the volatility of underlying security price can be used by investors to bet on such volatility in option market (Ni, Pan \& Poteshman, 2008). Ni et al. (2008) find that non-market maker is informative about the future realized volatility of underlying stocks and demand for volatility from trading volume of individual equity options. This is consistent with the argument that the volatility demands bring about increasing option price. More importantly, the price impact increases by $40 \%$ as informational asymmetry about stock volatility intensifies in the days leading up to earnings announcements and diminishes to its normal level soon after the volatility uncertainty is resolved. The most common reason for investors to trade in option is option market provides strategic flexibility to informed traders because they could trade contracts on the same underlying security but with different exercise prices and maturities (Kaul, Nimalendran, \& Zhang, 2004). Further, Chakravarty et al. (2004) and Kaul et al. (2004) suggest that informed traders would trade-off between options leverage and the transaction costs associated with the liquidity of options. Chen, Lung, and Tay (2005) discover feedback relations between trades in OTM options and the underlying equities. Some informed traders are probably attracted to the OTM options for their higher liquidity, lower premiums, and higher delta-to-premium ratios. Blasco, Corredor, and Santamaría (2010) reveal that potential informed trading in options markets is channeled basically through OTM options, whereas volatility trading mainly involves ATM options because of their liquidity.

Pan and Poteshman (2006) find that option trading volume provides informational content for future movement of stock prices. It takes several weeks to fully adjust stock price according to the information in option volume. Put-call ratios are also used to predict the future stock price movement. Stocks with low put-call ratios perform better than stocks with high put-call ratios. The predictability of stock price seems to be affected by valuable nonpublic information which traders utilize to trade.

The active option markets encourage market participants to gather private information that is relevant to long-term investments, which results in more efficient stock prices (Cao, 1999; Chakravarty, Gulen, \& Mayhew, 2004; Hu, 2014; Pan \& Poteshman, 2006). When stock prices are more efficient, other types of investors (less-informed investors) are more knowledgeable about the fundamental value of the firm. Options trading leads to better monitoring by enhancing informational efficiency, which encourage firms to invest in innovation (Blanco \& Wehrheim, 2017). Further, we examine the impact of option on quality of innovation which is manifested in firm market value (or stock market return).

Roll, Schwartz, and Subrahmanyam (2009) find that options market collect information faster than the stock market (informational efficiency). Moreover, firms with high volume of options trading will have higher market value, by controlling other determinants of value. Therefore, the stronger effect of options trading on firm valuation is associated with less information provided by analyst.

Therefore, we propose the following hypotheses:

H1: The impact of firm innovation on firm value in firm with option trading is stronger than in firm without option trading.

H2: The impact of firm innovation on stock market returns in firm with option trading is stronger than in firm without option trading.

\section{Data and Methodology}

\subsection{Data}

We use the RQ data sample from 1996 to 2009, which is obtained from database in Research Quotient of Wharton Research Data Services (WRDS). We sample the firms that are listed on US stock market. The data about option trading is acquired on OptionMetrics, which contains information on the daily number of contracts traded for each put and call option on U.S. publicly listed equities. We obtained financial data from Compustat and the Center for Research in Security Prices (CRSP) yearly stock file.

For representing broad industries in the market with high intensity of innovation, we choose firms from 5 industries, which are biotechnology industries, industrial and commercial machinery and computer equipment, electronics and communications, transportation equipment, and instruments and related products. The reason for choosing these specific industries are because firms in these industries have $R \& D$ who has a vital role for the long-run competitive advantage of firms (Blanco \& Wehrheim, 2017). Moreover, these sectors of industries have the highest ratio of R\&D expenditure and net sales among all industries (OECD, 2013). The distribution of industries in our sample is shown in Table 1. 
Table 1. Sample distribution

\begin{tabular}{cc}
\hline Firm's category & Number of Firms \\
\hline Biotechnology & 836 \\
Industrial and commercial machinery and computer equipment & 271 \\
Electronics and communications & 392 \\
Transportation equipment & 47 \\
Instrument and related products & 160 \\
Total & 1706 \\
\hline
\end{tabular}

Table 2 presents the Pearson correlation among all variables. Variable RD/BE has a negative and high correlation with R\&D tax shield. MTB as dependent variable has positive relation with its independent variables, except R\&D tax shield. For Fama-French regression, there are moderate correlation among Fama-French factors, such as between Mk-Rf and HML, Mk-Rf and UMD, SMB and UMD.

\subsection{Methodology}

\subsubsection{Research Quotient (RQ)}

Based on Cooper et al. (2015), RQ depicts the percentage increase of revenues from a $1 \%$ increase in R\&D investment, conditioning that other inputs and their elasticities are held constant. High RQ indicates a large number of innovations which are reasonably effective exploited them or small number of innovations which are extremely effective exploited them. RQ is represented by exponent $\gamma$ in firm $i$ 's production equation:

$$
Y=A_{i} K_{i, t}^{\alpha} L_{i, t}^{\beta} R_{i, t-1}^{\gamma} S_{i, t-1}^{\delta} D_{i, t}^{\emptyset} e_{i, t}
$$

Table 2. Correlation matrix

\begin{tabular}{|c|c|c|c|c|c|c|c|c|c|c|c|c|c|}
\hline $\begin{array}{c}\text { Correlation } \\
\text { Coeff. }\end{array}$ & $\begin{array}{c}\text { Ln } \\
\text { MTB }\end{array}$ & RQ & $\begin{array}{c}\text { RD tax } \\
\text { shield }\end{array}$ & $\mathrm{RD} / \mathrm{BE}$ & $\begin{array}{l}\text { Capex/ } \\
\text { asset }\end{array}$ & $1 / \mathrm{BE}$ & Rt-Rf & Mk-Rf & SMB & HML & UMD & $\begin{array}{c}\text { Past } \\
\text { perform }\end{array}$ & $\begin{array}{c}\text { Asset } \\
\text { growth }\end{array}$ \\
\hline Ln MTB & 1 & & & & & & & & & & & & \\
\hline RQ & 0.126 & 1 & & & & & & & & & & & \\
\hline RD taxshield & -0.06 & 0.03 & 1 & & & & & & & & & & \\
\hline $\mathrm{RD} / \mathrm{BE}$ & 0.106 & 0.005 & -0.884 & 1 & & & & & & & & & \\
\hline Capex/ asset & 0.081 & -0.057 & 0.011 & 0.023 & 1 & & & & & & & & \\
\hline $1 / \mathrm{BE}$ & 0.068 & -0.005 & -0.019 & 0.046 & 0.037 & 1 & & & & & & & \\
\hline Rt-Rf & 0.017 & -0.021 & 0.015 & -0.019 & -0.009 & 0.022 & 1 & & & & & & \\
\hline Mk-Rf & 0.001 & 0.034 & -0.02 & 0.013 & 0.019 & -0.014 & -0.152 & 1 & & & & & \\
\hline SMB & -0.03 & -0.009 & -0.003 & -0.01 & -0.015 & 0.052 & 0.146 & -0.076 & 1 & & & & \\
\hline HML & -0.011 & -0.012 & 0.015 & -0.003 & 0.01 & 0.024 & 0.073 & -0.418 & 0.057 & 1 & & & \\
\hline UMD & 0.041 & 0.024 & 0.003 & -0.001 & 0.005 & -0.02 & -0.156 & -0.454 & -0.365 & -0.102 & 1 & & \\
\hline Past perform & -0.032 & 0.02 & -0.018 & 0.028 & -0.041 & 0.027 & -0.005 & -0.017 & 0.125 & 0.037 & -0.083 & 1 & \\
\hline Asset growth & -0.012 & 0.009 & -0.065 & 0.064 & -0.007 & 0.008 & -0.189 & 0.105 & -0.065 & -0.017 & 0.035 & 0.142 & 1 \\
\hline
\end{tabular}

where $Y_{i, t}$ is output, $A_{i}$ is a firm fixed effect, $K_{i, t}$ is capital, $L_{i, t}$ is labor, $R_{i, t-1}$ is lagged R\&D one year relative to output, $S_{i, t-1}$ is lagged spillovers, $D_{i, t}$ is advertising.

$\mathrm{RQ}$ is an indicator which is universal and unitless since the data to estimate RQ can be received from financial data entirely. Thus, it can be applied to any firm which engages in R\&D. Moreover, the unitless characteristic of RQ make RQ become uniform measurement in interpreting across firms either within the same industry or across industries. Endogenous growth theory (Knott \& Vieregger, 2014) proposes that RQ empirically can be a proxy for firm R\&D investment, firm value and growth.

Random coefficient model is used to capture RQ for each firm year or to estimate R\&D elasticity because each coefficient has two components: First, the direct effect of the explanatory variable. Second, the random component that proxies for the effects of omitted variables or firm-specific error, that are denoted by $\beta_{-}$and $\beta_{-} \mathrm{i}$, such as given in equation (2):

$$
\begin{gathered}
\ln Y_{i t}=\left(\beta_{0}+\beta_{0 i}\right)+\left(\beta_{1}+\beta_{1 i}\right) \ln K_{i t}+\left(\beta_{2}+\beta_{2 i}\right) \ln L_{i t}+\left(\beta_{3}+\beta_{3 i}\right) \ln R_{i, t-1}+\left(\beta_{4}+\beta_{4 i}\right) \ln S_{i, t-1}+ \\
\left(\beta_{5}+\beta_{5 i}\right) \ln D_{i t}+\varepsilon_{i t}
\end{gathered}
$$


where $Y_{i, t}$ is revenues, $K_{i, t}$ is capital such as net property, plant, and equipment, $L_{i, t}$ is labor as full-time equivalent employees, in units of $1000, D_{i, t}$ is advertising, $R_{i, t}$ is R\&D. Using the random coefficient model, we draw the line between each coefficient in equation (2) and the each of the exponent in equation (1), e.g, $\left(\beta_{3}+\beta_{3 i}\right)$ corresponds to $\gamma$ in equation (1).

Another important factor is $S_{i, t}$ (firm-specific spillovers), which measures the density of number of firms with superior knowledge as well as the amount of surfeit knowledge of each firm relative to the focal firm. Firm-specific spillover $\left(S_{i, t}\right)$ is computed as the sum of differences in knowledge between focal firm $\mathrm{i}$ and rival firm $\mathrm{j}$ for all firms in the four digit SIC industry with more knowledge (R\&D) than the focal firm.

$$
S_{i, t}=\sum_{j \neq i} R_{j, t}-R_{i, t} \forall R_{j, t} \geq R_{i, t}
$$

\subsubsection{The Impacts of Option Trading (Option Volume) on Firm Value and Stock Return}

We examine the impact of option trading on the relationship between firm innovation using RQ and contemporaneous firm value as measured by Market-to-Book Ratios (MTB).

$$
\begin{aligned}
& \ln \left(M_{T B} B_{i, t}\right)=\alpha+\beta_{1} * R Q_{i, t}+\beta_{2} * R Q_{i, t} * \text { Option Dummy }+\gamma * \text { Controls }+\varepsilon_{i, t} \\
& \ln \left(M T B_{i, t}\right)=\alpha+\beta_{1} * R Q_{i, t}+\beta_{2} * R Q_{i, t} * \text { Option Volume }+\gamma * \text { Controls }+\varepsilon_{i, t}
\end{aligned}
$$

where option dummy is 1 for firm with option trading and 0 for firm without option trading. Controlled variables are abnormal earnings, $R \& D$ tax shield, $R \& D$ expenditures scaled by total book equity, capital expenditure scaled by total book assets, total book equity. Ernst (2012) states that taxation has an impact on research, development and innovation. In recent years, many OECD members have introduced or modified specific tax incentives to raise the business expenses for research and development. Expenses for research and development $(\mathrm{R} \& \mathrm{D})$ could generate a tax shield that reduces the firms' tax base. Yet, taxation also reduces the yield from innovation.

Scholes and Wolfson (1992) stated that reinvestment in R\&D can be seen as an effort to generate tax shield as government's contribution to increase the role of $R \& D$ in increasing future earnings. They point out that prices of tax-favored investments increase by the present value of the tax savings. Thus, R\&D tax shield must be value-relevant. Relating to multicollinearity in regression, when the $R \& D$ value highly correlated with $R \& D$ tax shield, then the failure to control explicitly for R\&D tax shield variable results in inflated standard errors. The variable $V_{t} \tau_{t}$ represents the tax shield from expensing $R \& D$, and $\beta_{2}$ indicates the rate at which $R \& D$ tax shields are valued. $V$ is $R \& D$ expenditures at time $t$; and $\tau_{t}$ is the firm's tax rate at time $t$. Thus, $R \& D$ tax shield is $R \& D$ expenses multiplied by effective tax rate (Sougiannis, 1994).

According to our hypotheses, coefficient value of $\beta_{2}$ in equation (4) and (5) should be positive for firms with option trading. Because option market's ability to collect information is faster than stock market, firms with high volume of options trading should have higher market value (Roll et al., 2009). Moreover, informational efficiency, as impact of actively traded options, reduces the risk of investing in an asset because market prices reflect information more precisely. This phenomenon would tend to make the asset more valuable. Thus, welfare of both informed and uninformed traders are simply improved in trading options by completing markets, and thus affect market valuations (Conrad, 1989).

We use Fama-French three factor model (Fama and French, 1993) with Carhart's momentum factor (Carhart, 1997) to modify stock returns. The asset pricing model previously relied on capital asset pricing model (CAPM) which has one variable, return of the market portfolio, as benchmark of the normal return to a stock. Fama and French make some improvement to the formula and add two more factors: market capitalization and market to book (value stock) to reflect portfolio's exposure. Moreover, price momentum proposed by Carhart (1997) is added to form the Fama-French-Momentum 4-factor (FFM4).

$$
\begin{gathered}
R_{t}-R_{f t}=\alpha_{i}+\beta_{1 i}\left(R_{m t}-R_{f t}\right)+\beta_{2} S M B_{t}+\beta_{3} H M L_{i}+\beta_{4} U M D_{i}+\beta_{5} * R Q_{i, t}+\beta_{6} * R Q_{i, t} * \\
\text { Option Dummy }+\gamma * \text { Controls }+\varepsilon_{i, t} \\
R_{t}-R_{f t}=\alpha_{i}+\beta_{1 i}\left(R_{m t}-R_{f t}\right)+\beta_{2} S M B_{t}+\beta_{3} H M L_{i}+\beta_{4} U M D_{i}+\beta_{5} * R Q_{i, t}+\beta_{6} * R Q_{i, t} * \\
\text { Option Volume }+\gamma * \text { Controls }+\varepsilon_{i, t}
\end{gathered}
$$

where $\mathrm{t}$ is subscript for time of the estimation window, $\mathrm{i}$ is subscript for announcement, $R_{t}$ is stock returns on day $\mathrm{t}, R_{m t}$ is returns of the market portfolio, $R_{f t}$ is risk-free return rate, SMB is returns on portfolio of small stocks minus returns on large stock, HML is returns on portfolio of stocks with high book-to-market ratio minus the returns to a portfolio of stock with low book-to-market ratio, and UMD is Carhart's price-momentum factor that captures one-year momentum in returns. 
For risk free rate, we use three months U.S. Treasury bill rate. Fama and French (1992) find that three-factor model can explain better than CAPM, since three-factor model explains over $90 \%$ of diversified portfolios returns, while CAPM explains about $70 \%$ only. Moreover, they also find positive returns from small-size and high book-to-market ratios firms.

The relationship of monthly future returns and RQ can be investigated using Fama French (1993) regression model. We control other factors which can affect return, such as firm market capitalization, book-to-market equity, past return performance, and asset growth. According to Fama and French (1992), we use predictors constructed from fiscal year data ending in calendar year $t$ to predict stock returns from July in year $t+1$ to June in year $\mathrm{t}+2$. If we use fiscal year data from 1993 to 2006, then the final monthly return dataset is from July 1994 to June 2009. Past performance is measured as the compounded buy and hold return of the prior six months returns from month t-7 to t-2 for month t. Then, we estimate monthly cross sectional regression for each month and report the time series average of coefficients. Computing standard errors are based on the time series variation of coefficients.

In accordance with our hypotheses, the coefficient value of $\beta_{6}$ from equations (6) and (7) should be positive, indicating that the impacts of RQ on return are larger for firms with option trading. According to Ni et al. (2008), non-market maker is informative about the future realized volatility of underlying stocks and demand for volatility from trading volume of individual equity options. The price impact increases by $40 \%$ as informational asymmetry about stock volatility intensifies in the days leading up to earnings announcements and diminishes to its normal level soon after the volatility uncertainty is resolved. This evidence is reinforced by Pan and Poteshman (2006) that option trading volume bring informational content for future movement of stock prices. The active options market encourage market participants to gather private information that is relevant to long-term investment, which result in more efficient stock prices, then leads to reduction of asymmetric information problems about R\&D.

\subsection{Summary Statistics}

Using data for at least 10 years observation for each company, Table 3 display all main variables used. We have removed all the missing and/ or irrelevant data into 1706 samples data. The average value of samples of total assets is $\$ 10.474$ million and average market value of samples is $\$ 14,812$ million. The average RQ is 0.098 (standard deviation of 0.06) with a 95th percentile of 0.193. While for future stock return (Rt-Rf), past performance and asset growth only have 1572 samples data, because some data are incomplete. The average value of future stock return is -0.035 , whereas average value of past performance is -0.039 . Last, the average value of asset growth is 0.111 .

Table 3. Summary statistic

\begin{tabular}{lcccccccc}
\hline Variable & $\mathrm{N}$ & mean & $\mathrm{Stdev}$ & Min & 5 Pct & Median & 95 Pct & Max \\
\hline RQ & 1706 & 0.098 & 0.060 & -0.520 & 0.017 & 0.097 & 0.193 & 0.397 \\
Firm characteristic & & & & & & & & \\
Total assets & 1706 & 10474.545 & 36982.654 & 2.817 & 10.767 & 465.668 & 43141.534 & 479921.000 \\
Revenue & 1706 & 6999.223 & 20617.844 & 0.778 & 7.862 & 366.301 & 32011.900 & 190812.000 \\
R\&D expense & 1706 & 628.719 & 1484.378 & 0.000 & 0.454 & 23.874 & 4003.000 & 12183.000 \\
Market equity (in million) & 1706 & 14.812 & 36.589 & $8.864 \mathrm{e}-05$ & 0.011 & 0.690 & 85.501 & 459.623 \\
Book equity & 1706 & 3701.659 & 8728.140 & -0.300 & 6.594 & 284.773 & 19182.870 & 107792.000 \\
R\&D/assets & 1706 & 0.084 & 0.072 & 0.000 & 0.011 & 0.067 & 0.209 & 0.680 \\
Capital expenditure & 1706 & 493.845 & 2283.515 & 0.000 & 0.161 & 15.664 & 1822.899 & 33143.000 \\
capex/assets & 1706 & 0.045 & 0.048 & 0.000 & 0.006 & 0.033 & 0.124 & 0.543 \\
leverage & 1706 & 0.828 & 13.935 & -0.407 & 0.000 & 0.099 & 1.482 & 522.444 \\
Ln MTB & 1706 & 7.864 & 1.040 & -0.863 & 6.489 & 7.912 & 9.367 & 12.020 \\
R\&D/BE & 1706 & 0.291 & 5.018 & -9.490 & 0.019 & 0.106 & 0.413 & 205.333 \\
Abnormal earnings & 1706 & 0.066 & 1.784 & -64.838 & -0.394 & 0.107 & 0.517 & 19.552 \\
Option volume & 1706 & 2072200 & 5464561 & 14 & 3478.9 & 271935 & 11457280 & 71644806 \\
Rt-Rf & 1572 & -0.035 & 0.520 & -4.248 & -0.890 & -0.014 & 0.759 & 2.801 \\
Past perform & 1572 & -0.039 & 0.385 & -2.848 & -0.680 & -0.014 & 0.573 & 1.944 \\
Asset growth & 1572 & 0.111 & 0.311 & -3.218 & -0.247 & 0.078 & 0.612 & 2.722 \\
\hline
\end{tabular}

Note. Detailed variable definitions can be found in Appendix. 
Table 4 sorts the RQ from the smallest to largest into quintiles and display the average of all major variables for each quintiles. The quintiles are sorting based on contemporaneous RQ. The sorted RQ ranges from the 1 st quintile (0.024) to 5th quintile (0.175). Looking over the quintiles, we got non-monotonic result with firm characteristics, such as total assets, revenue, and R\&D expense showing that they have increasing pattern from quintile 1 to 4, but drop in quintile 5. Finally, natural logarithm of Market-to-Book ratio of equity has similar pattern with RQ. Thus, RQ appears correlated with firm value. Firm characteristics also have correlation with $\mathrm{RQ}$ as long as the value of RQ is not over high. When too much fund is allocated to R\&D only, it creates imbalance to their finance and sacrifices other department that already has a good capability in creating revenues.

Table 4. Summary statistics by Research Quotient (RQ) quintiles

\begin{tabular}{lcccccc}
\hline Variable & $\mathrm{N}$ & 1 & 2 & 3 & 4 & 5 \\
\hline RQ & 1706 & 0.024 & 0.077 & 0.097 & 0.119 & 0.175 \\
Firm characteristic & & & & & & \\
Total assets & 1706 & 2208.473 & 12205.07 & 13034.8 & 18540.07 & 6193.417 \\
Revenue & 1706 & 1326.466 & 7639.555 & 8888.652 & 12043.51 & 4904.739 \\
R\&D expense & 1706 & 180.302 & 677.026 & 788.465 & 1097.072 & 401.395 \\
Market equity (million) & 1706 & 3.700 & 14.516 & 17.303 & 26.983 & 11.566 \\
Book equity & 1706 & 1153.186 & 3691.589 & 4469.249 & 6691.585 & 2506.19 \\
R\&D/assets & 1706 & 0.081 & 0.076 & 0.083 & 0.081 & 0.096 \\
Capital expenditure & 1706 & 99.696 & 537.865 & 683.050 & 872.564 & 276.344 \\
capex/assets & 1706 & 0.049 & 0.048 & 0.047 & 0.042 & 0.038 \\
leverage & 1706 & 0.313 & 1.157 & 2.041 & 0.360 & 0.323 \\
MTB & 1706 & 7.670 & 7.666 & 7.883 & 8.004 & 8.100 \\
R\&D/BE & 1706 & 0.146 & 0.178 & 0.813 & 0.155 & 0.165 \\
Abnormal earnings & 1706 & -0.017 & 0.051 & -0.016 & 0.168 & 0.142 \\
Option volume & 1706 & 381410.2 & 1108288 & 1036689 & 2132772 & 1013167 \\
Rt-Rf & 1572 & -0.08 & 0.00 & -0.02 & -0.05 & -0.03 \\
Past perform & -0.03 & -0.06 & -0.02 & -0.05 & -0.04 \\
Asset growth & 1572 & 0.11 & 0.08 & 0.11 & 0.11 & 0.15 \\
\hline
\end{tabular}

\section{Empirical Results \& Discussion}

\subsection{Effect of Option Trading on Firm Value and Stock Return}

Higher productivity of R\&D is associated with higher firm value. The firms innovate their product, and perform better than their competitors. Better performance will gain trust from investors. Investors believe that this company will have bright prospect and buy the shares of that company. Then, stock price goes up and firm value increases.To understand whether option trading has the impact on the relation between RQ and firm value, we run the regression in equations (4) and (5). We use four control variables, which are R\&D tax shield, R\&D expenditure/book equity, capital expenditure/ assets, and book equity. Abnormal earnings is omitted because it has high collinearity effect with R\&D expenditure. In Table 5, model (2) shows that RQ has positive and significant impact on MTB at $1 \%$ level. Every 0.1 unit increase of RQ have $22.02 \%$ increase in MTB, while all other variables in the model are held constant. Thus, higher RQ is associated with higher MTB.

Table 5. Regressions of Market-to-Book on contemporaneous Research Quotient (RQ) under the effect of option trading

\begin{tabular}{|c|c|c|c|c|c|c|c|c|}
\hline $\ln$ MTB & $(1)$ & & (2) & & (3) & & (4) & \\
\hline \multirow[t]{2}{*}{ Constant } & 7.647 & $* * *$ & 7.533 & $* * *$ & 7.626 & $* * *$ & 7.511 & $* * *$ \\
\hline & (159.8) & & (139.8411) & & (158.5) & & (138.9959) & \\
\hline \multirow[t]{2}{*}{ RQ } & 2.213 & $* * *$ & 2.202 & $* * *$ & 4.541 & $* * *$ & 4.59 & $* * *$ \\
\hline & $(5.331)$ & & $(5.3647)$ & & $(5.652)$ & & $(5.7313)$ & \\
\hline \multirow[t]{2}{*}{ RQ*opt dummy } & & & & & 1.475 & $* * *$ & 1.51 & $* * *$ \\
\hline & & & & & $(3.380)$ & & $(3.4679)$ & \\
\hline \multirow[t]{2}{*}{ RD tax shield } & & & 0.769 & $* *$ & & & 0.683 & $* *$ \\
\hline & & & $(2.5716)$ & & & & $(2.2846)$ & \\
\hline
\end{tabular}




\begin{tabular}{|c|c|c|c|c|c|c|}
\hline Capex/assets & & $\begin{array}{r}1.649 \\
(3.166)\end{array}$ & $* * *$ & & $\begin{array}{r}1.657 \\
(3.1933)\end{array}$ & $* * *$ \\
\hline $\mathrm{RD} / \mathrm{BE}$ & & $\begin{array}{r}0.045 \\
(4.4436)\end{array}$ & $* * *$ & & $\begin{array}{r}0.042 \\
(4.1461)\end{array}$ & $* * *$ \\
\hline $1 / \mathrm{BE}$ & & $\begin{array}{r}0.248 \\
(3.0749)\end{array}$ & $* * *$ & & $\begin{array}{r}0.282 \\
(3.4851)\end{array}$ & $* * *$ \\
\hline Observations & 1705 & 1694 & & 1705 & 1694 & \\
\hline R-squared & 0.0164 & 0.0458 & & 0.0230 & 0.0526 & \\
\hline
\end{tabular}

Note. Detailed variable definitions can be found in Appendix. T-statistics are reported in parenthesis. P value is reported in star sign ***, **,

* denote significant at $1 \%, 5 \%, 10 \%$ level.

The result of model (4) in Table 5 are consistent with our hypothesis that the impact of firm innovation on MTB with option trading is stronger than that without option trading. That is, the impact of RQ on MTB with option trading is significantly higher than that without option trading at $1 \%$ level, while all other variables in the model are held constant.

We also examine whether option trading lead to increase or decrease its firm value and future stock return. Our finding indicates that firm with option trading have lower firm value than firms without option trading. The decrease of firm value could be due to traders believe options have some superior benefits than stock. According to Jennings and Starks (1986), those traders consider to use option trading as substitute for stock trading, since options trading have lower transaction cost and higher leverage, even they think options may be preferred to direct equity investment. This condition can lead to the decline of shares outstanding, then make the firm value goes down. The number of options volume have the same direction with firm value, because options trading reduce information asymmetry, which lead to better control of R\&D productivity.

Future stock return is difficult to predict. Many events or factors, either big or small changes result in stock price fluctuation. Good event or announcement, such as better earnings announcement, will trigger stock price increase, otherwise it will cause stock price goes down, such as low dividend yield predicts low future stock return (Patelis, 1997). However, some specialized characteristic which are owned by a company can induce their stock price either higher or lower than the other companies.

Afterward, we investigate the predictive power of RQ on future stock market return. We control Fama-French factors, which are Mk-Rf, SMB, HML, UMD. In addition, we also control past return performance and asset growth. To explore whether option trading has the impact on relation between RQ and future stock return, we run equations (6) and (7).

Model (3) in Table 6 shows that RQ has negative impact on future stock return but not significant. Nonetheless, the book-to-market value, portfolio return, and the asset growth have significant impact on future stock return.

From model (4) and (5) in Table 6, the impact of option dummy on the relation between future stock return and RQ is positive and insignificant. However, the probability value almost reach $10 \%$ level of significant. It indicates that the predictive power of RQ in a company with option trading is slightly higher than that without option trading. One characteristic that can induce stock price become higher is option trading. Our finding document that firms with option trading tend to have future stock return higher than firms without option trading. The reason of this phenomenon can be explained by Roll, Schwarz, \& Subrahmanyam (2008) that options market collect information faster than the stock market (informational efficiency).

Table 6. Regressions of future stock market return on Research Quotient (RQ) under the effect of option dummy

\begin{tabular}{|c|c|c|c|c|c|c|c|c|c|c|}
\hline Rt-Rf & (1) & & (2) & & (3) & & (4) & & (5) & \\
\hline \multirow[t]{2}{*}{ Constant } & -0.127 & $* * *$ & -0.112 & $* * *$ & -0.1255 & $* * *$ & -0.1183 & $* * *$ & -0.1093 & $* * *$ \\
\hline & $(-6.873)$ & & $(-4.1665)$ & & $(-4.4299)$ & & $(-4.2707)$ & & $(-3.9068)$ & \\
\hline \multirow[t]{2}{*}{ Mk-Rf } & -0.105 & $* * *$ & -0.105 & $* * *$ & -0.0933 & $* * *$ & -0.1129 & $* * *$ & -0.0975 & $* * *$ \\
\hline & $(-10.349)$ & & $(-9.9378)$ & & $(-9.0999)$ & & $(-10.9856)$ & & $(-9.8698)$ & \\
\hline \multirow[t]{2}{*}{ SMB } & 0.007 & & 0.0067 & & 0.031849 & $*$ & 0.0253 & & 0.0303 & $*$ \\
\hline & $(0.405)$ & & $(0.4118)$ & & (1.8319) & & (1.5779) & & (1.8112) & \\
\hline \multirow[t]{2}{*}{ HML } & -0.042 & $* * *$ & -0.0426 & $* * *$ & -0.0355 & $* * *$ & -0.0556 & $* * *$ & -0.0425 & $* * *$ \\
\hline & $(-3.291)$ & & $(-3.4656)$ & & $(-2.9071)$ & & $(-4.5753)$ & & $(-3.5118)$ & \\
\hline UMD & -0.089 & $* * *$ & -0.0895 & $* * *$ & -0.0836 & & -0.0984 & $* * *$ & -0.0867 & $* * *$ \\
\hline
\end{tabular}




\begin{tabular}{|c|c|c|c|c|c|c|c|c|}
\hline & $(-10.155)$ & $(-9.5778)$ & $(-9.3530)$ & & $(-11.7813)$ & & $(-10.0964)$ & \\
\hline \multirow[t]{2}{*}{$\ln (1+\mathrm{RQ})$} & & -0.1598 & -0.1456 & & -0.6964 & $*$ & -0.7584 & $*$ \\
\hline & & $(-0.7485)$ & $(-0.6380)$ & & $(-1.7139)$ & & $(-1.8386)$ & \\
\hline \multirow[t]{2}{*}{ RQ*optdum } & & & & & 0.3618 & & 0.3810 & \\
\hline & & & & & (1.5499) & & (1.643) & \\
\hline \multirow[t]{2}{*}{$\ln (1+$ pastperform $)$} & & & -0.0333 & & & & -0.0211 & \\
\hline & & & $(-1.0412)$ & & & & $(-0.6719)$ & \\
\hline \multirow[t]{2}{*}{ asset growth } & & & -0.2606 & $* * *$ & & & -0.2502 & $* * *$ \\
\hline & & & $(-5.0411)$ & & & & $(-4.9914)$ & \\
\hline Observations & 1572 & 1572 & 1545 & & 1572 & & 1545 & \\
\hline R-squared & 0.0944 & 0.0947 & 0.1188 & & 0.1306 & & 0.1316 & \\
\hline
\end{tabular}

Note. This table reports regression of yearly future returns from July of year $\mathrm{t}+1$ to June of year $\mathrm{t}+2$ on RQ in fiscal year ending in year $\mathrm{t}$. Detailed variable definitions can be found in Appendix. T-statistics are reported in parenthesis. $\mathrm{P}$ value is reported in star sign ***, **, * denote significant at $1 \%, 5 \%, 10 \%$ level.

Table 7 presents that past performance and asset growth have significant impact on current stock returns at $1 \%$ and 5\% significant level. We find that in models (4) and (5), current stock return react insignificantly negative to the increase of firm innovation or RQ. There is no significant relationship between RQ and current stock return. According to those two models, we also document that the impact of RQ on current stock return with option trading is higher than that without option trading. Unfortunately, this result is not significant enough.

Table 7. Regressions of current stock market return on Research Quotient (RQ) under the effect of option trading

\begin{tabular}{|c|c|c|c|c|c|c|c|c|c|c|}
\hline Rt-Rf & (1) & & (2) & & (3) & & (4) & & (5) & \\
\hline \multirow[t]{2}{*}{ Constant } & -0.0602 & $* * *$ & -0.0931 & $* * *$ & -0.0856 & $* * *$ & -0.0918 & $* * *$ & -0.0786 & $* * *$ \\
\hline & $(-3.0186)$ & & $(-3.0957)$ & & $(-2.8052)$ & & $(-3.0783)$ & & $(-2.5927)$ & \\
\hline \multirow[t]{2}{*}{ Mk-Rf } & 0.016 & & 0.0297 & $* *$ & 0.0284 & $* *$ & 0.0312 & $* *$ & 0.0240 & $* *$ \\
\hline & (1.3845) & & (2.3846) & & $(2.3282)$ & & (2.4898) & & (2.0162) & \\
\hline \multirow[t]{2}{*}{ SMB } & 0.0483 & $* * *$ & 0.0407 & $* *$ & 0.0451 & $* *$ & 0.0353 & $*$ & 0.035476 & $*$ \\
\hline & (2.6849) & & (2.1841) & & $(2.4516)$ & & (1.9231) & & (1.9576) & \\
\hline \multirow[t]{2}{*}{ HML } & 0.0028 & & 0.0174 & & 0.0214 & & 0.0205 & & 0.0188 & \\
\hline & $(0.2093)$ & & (1.1937) & & (1.5031) & & $(1.4222)$ & & (1.351) & \\
\hline \multirow[t]{2}{*}{ UMD } & -0.0027 & & -0.0126 & & -0.0109 & & -0.0134 & & -0.0154 & $*$ \\
\hline & $(-0.2659)$ & & $(-1.4526)$ & & $(-1.2547)$ & & $(-1.5024)$ & & $(-1.8108)$ & \\
\hline \multirow[t]{2}{*}{$\ln (1+\mathrm{RQ})$} & & & 0.108 & & 0.1416 & & -0.2661 & & -0.2780 & \\
\hline & & & $(0.4256)$ & & $(0.5521)$ & & $(-0.6229)$ & & $(-0.6636)$ & \\
\hline \multirow[t]{2}{*}{ RQ*optdum } & & & & & & & 0.2136 & & 0.2818 & \\
\hline & & & & & & & $(0.8905)$ & & (1.2102) & \\
\hline \multirow[t]{2}{*}{ Past perform } & & & & & -0.1137 & $* * *$ & & & -0.1144 & $* * *$ \\
\hline & & & & & $(-2.7613)$ & & & & $(-2.8372)$ & \\
\hline \multirow[t]{2}{*}{ asset growth } & & & & & -0.1093 & $* *$ & & & -0.1148 & $* *$ \\
\hline & & & & & $(-2.2439)$ & & & & $(-2.3831)$ & \\
\hline Observations & 1647 & & 1647 & & 1647 & & 1647 & & 1647 & \\
\hline R-squared & 0.0081 & & 0.0194 & & 0.0259 & & 0.0197 & & 0.0276 & \\
\hline
\end{tabular}

Note. Detailed variable definitions can be found in Appendix. T-statistics are reported in parenthesis. P value is reported in star sign ***, **,

$*$ denote significant at $1 \%, 5 \%, 10 \%$ level.

\subsection{Effect of Option Volume on Firm Value and Stock Return}

If we use option volume instead of option dummy, model (4) in Table 8 exhibits that both RQ and interaction term of RQ and option volume has positive and significant impact on MTB at $1 \%$ level. These result supports hypothesis 1 that more option volume is accompanied with higher impact of RQ on the firm value. Therefore, option volume is a better proxy of option trading than option dummy in examining the impact of option trading on the relation between RQ and MTB.

Table 8. Regressions of Market-to-Book on contemporaneous Research Quotient (RQ) under the effect of option 
volume

\begin{tabular}{|c|c|c|c|c|c|c|c|c|}
\hline $\ln$ MTB & $(1)$ & & (2) & & (3) & & (4) & \\
\hline \multirow[t]{2}{*}{ Constant } & 7.647 & $* * *$ & 7.533 & $* * *$ & 7.634 & $* * *$ & 7.529 & $* * *$ \\
\hline & (159.8) & & (139.841) & & (160.186) & & $(140.275)$ & \\
\hline \multirow[t]{2}{*}{ RQ } & 2.213 & $* * *$ & 2.202 & $* * *$ & 2.008 & $* * *$ & 2.005 & $* * *$ \\
\hline & (5.331) & & $(5.365)$ & & $(4.827)$ & & $(4.871)$ & \\
\hline \multirow[t]{2}{*}{ RQ*opt volume } & & & & & 2.33E-07 & $* * *$ & $2.23 \mathrm{E}-07$ & $* * *$ \\
\hline & & & & & $(4.160)$ & & (4.049) & \\
\hline \multirow[t]{2}{*}{ RD tax shield } & & & 0.769 & $* *$ & & & 0.746 & $* *$ \\
\hline & & & (2.572) & & & & $(2.506)$ & \\
\hline \multirow[t]{2}{*}{ Capex/assets } & & & 1.649 & $* * *$ & & & 1.5904 & $* * *$ \\
\hline & & & (3.166) & & & & $(3.066)$ & \\
\hline \multirow[t]{2}{*}{$\mathrm{RD} / \mathrm{BE}$} & & & 0.045 & $* * *$ & & & 0.043 & $* * *$ \\
\hline & & & (4.4436) & & & & (4.335) & \\
\hline \multirow[t]{3}{*}{$1 / \mathrm{BE}$} & & & 0.248 & $* * *$ & & & 0.261 & $* * *$ \\
\hline & & & (3.0749) & & & & $(3.243)$ & \\
\hline & & & & & & & & $* * *$ \\
\hline Observations & 1705 & & 1694 & & 1704 & & 1693 & \\
\hline R-squared & 0.0164 & & 0.0458 & & 0.0263 & & 0.0549 & \\
\hline
\end{tabular}

Note. Detailed variable definitions can be found in Appendix. T-statistics are reported in parenthesis. P value is reported in star sign $* * *, * *$,

$*$ denote significant at $1 \%, 5 \%, 10 \%$ level.

In Table 9, we find that the interaction terms of RQ and option volume are positive and significant at $10 \%$ level. These result supports hypothesis 2 that the impact of firm innovation on stock market returns in firm with option trading is stronger than in firm without option trading. A unit increase of RQ*option volume is associated with 0.0003 (0.0004) decrease in future stock return in models 4 (5).

Table 9. Regressions of future stock market return on Research Quotient (RQ) under the effect of option volume

\begin{tabular}{|c|c|c|c|c|c|c|c|c|c|c|}
\hline Rt-Rf & (1) & & (2) & & (3) & & (4) & & (5) & \\
\hline Constant & $\begin{array}{r}-0.127 \\
(-6.873)\end{array}$ & $* * *$ & $\begin{array}{r}-0.112 \\
(-4.1665)\end{array}$ & $* * *$ & $\begin{array}{r}-0.1255 \\
(-4.4299)\end{array}$ & $* * *$ & $\begin{array}{r}-0.1267 \\
(5.0968)\end{array}$ & $* * *$ & $\begin{array}{c}-0.0677 \\
(3.2818)\end{array}$ & $* * *$ \\
\hline Mk-Rf & $\begin{array}{r}-0.105 \\
(-10.349)\end{array}$ & $* * *$ & $\begin{array}{r}-0.105 \\
(-9.9378)\end{array}$ & $* * *$ & $\begin{array}{r}-0.0933 \\
(-9.0999)\end{array}$ & $* * *$ & $\begin{array}{r}-0.1111 \\
(-10.6735)\end{array}$ & $* * *$ & $\begin{array}{r}-0.103 \\
(10.0852)\end{array}$ & $* * *$ \\
\hline SMB & $\begin{array}{r}0.007 \\
(0.405)\end{array}$ & & $\begin{array}{r}0.0067 \\
(0.4118)\end{array}$ & & $\begin{array}{r}0.0318 \\
(1.8319)\end{array}$ & $*$ & $\begin{array}{r}0.0164 \\
(0.9953)\end{array}$ & & $\begin{array}{c}-0.0454 \\
(-3.0368)\end{array}$ & $* * *$ \\
\hline HML & $\begin{array}{r}-0.042 \\
(-3.291)\end{array}$ & $* * *$ & $\begin{array}{r}-0.0426 \\
(-3.4656)\end{array}$ & $* * *$ & $\begin{array}{r}-0.0355 \\
(-2.9071)\end{array}$ & $* * *$ & $\begin{array}{c}-0.0518 \\
(4.2236)\end{array}$ & $* * *$ & $\begin{array}{c}-0.0329 \\
(-2.6975)\end{array}$ & $* * *$ \\
\hline UMD & $\begin{array}{r}-0.089 \\
(-10.155)\end{array}$ & $* * *$ & $\begin{array}{r}-0.0895 \\
(-9.5778)\end{array}$ & $* * *$ & $\begin{array}{r}-0.0836 \\
(-9.3530)\end{array}$ & $* * *$ & $\begin{array}{r}-0.0978 \\
(11.3801)\end{array}$ & $* * *$ & $\begin{array}{l}-0.1019 \\
(1.0110)\end{array}$ & $* * *$ \\
\hline $\ln (1+R Q)$ & & & $\begin{array}{r}-0.1598 \\
(-0.7485)\end{array}$ & & $\begin{array}{r}-0.1456 \\
(-0.6380)\end{array}$ & & $\begin{array}{r}-0.0426 \\
(0.2250)\end{array}$ & & $\begin{array}{c}-0.2508 \\
(-4.3220)\end{array}$ & $* * *$ \\
\hline RQ*optvol & & & & & & & $\begin{array}{r}0.0003 \\
(1.9886)\end{array}$ & $*$ & $\begin{array}{r}0.0004 \\
(1.9011)\end{array}$ & $*$ \\
\hline $\ln (1+$ pastperform $)$ & & & & & $\begin{array}{r}-0.0333 \\
(-1.0412)\end{array}$ & & & & $\begin{array}{r}-0.128 \\
(-4.3950)\end{array}$ & $* * *$ \\
\hline asset growth & & & & & $\begin{array}{r}-0.2606 \\
(-5.0411)\end{array}$ & $* * *$ & & & $\begin{array}{c}-0.2903 \\
(-5.7511)\end{array}$ & $* * *$ \\
\hline Observations & 1572 & & 1572 & & 1545 & & 1572 & & 1545 & \\
\hline R-squared & 0.0944 & & 0.0947 & & 0.1188 & & 0.1176 & & 0.11661 & \\
\hline
\end{tabular}

Note. This table reports regression of yearly future returns from July of year $\mathrm{t}+1$ to June of year $\mathrm{t}+2$ on RQ in fiscal year ending in year $\mathrm{t}$. Detailed variable definitions can be found in Appendix. T-statistics are reported in parenthesis. $\mathrm{P}$ value is reported in star sign ***, **, * denote significant at $1 \%, 5 \%, 10 \%$ level. 


\section{Conclusion}

In the literature, innovation is mostly measured by patent. Nonetheless, many companies don't patent their new product. Therefore, firms without patent does not mean they are not innovating. The alternative way to solve this problem is to use Research Quotient (RQ) as firm innovation measurement. Since RQ is defined as the ability of firm to generate revenues from its budget that allocated for R\&D investment, using RQ is a better indicator for firm innovation.

In this paper, we explore whether the impact of RQ on MTB and future return in firm with option trading is stronger than firm without option trading. We find that RQ has positive and significant impact on MTB at $1 \%$ significance level. The impact of option dummy, which is firm with or without option trading, on the relation between MTB and RQ is positive and significant at 1\% significance level, whereas the impacts of firm innovation on future stock return in firms with option trading is insignificantly stronger than those without option trading.

The effect of option volume also exhibits that both RQ and interaction term of RQ and option volume has positive and significant impact on MTB at $1 \%$ level. Moreover, option volume has significant effect toward the impact of $\mathrm{RQ}$ on future stock return. The effect of interaction term of $\mathrm{RQ}$ and option volume is positive and significant.

There are some drawbacks that could affect our results. Our sample period is not long enough. Longer period will make this research more compatible in capturing phenomenon. In process of collecting data, such as RQ and some financial data, some data are not complete. Not every company is listed on RQ database. Even the company is listed, the range of period that we are looking for are not complete. Our regression use cross-section data set, instead of panel data set because we can't get all samples data in the same range of period. If we insist on using panel data set, we will cut many samples and our research becomes less representative to actual data.

Since our study use U.S. market, further research can try new market, such as Europe market or Asia market, like China, Korea, or Japan. Moreover, the new research can try a new point of view from other industry. With enough resources of innovation announcement, further research can contribute more on the impact of innovation on future stock return.

\section{References}

Artz, K. W., Norman, P. M., Hatfield, D. E., \& Cardinal, L. B. (2010). A Longitudinal Study of the Impact of R\&D, Patents, and Product Innovation on Firm Performance. Journal of Product Innovation Management, 27(5), 725-740. http://doi.org/10.1111/j.1540-5885.2010.00747.x

Blanco, I., \& Wehrheim, D. (2017). The Bright Side of Financial Derivatives: Options Trading and Firm Innovation. Journal of Financial Economics, forthcoming. http://doi.org/10.2139/ssrn.2586441

Blasco, N., Corredor, P., \& Santamaría, R. (2010). Does informed trading occur in the options market? Some revealing clues. Accounting \& Finance, 50(3), 555-579. http://doi.org/10.1111/j.1467-629X.2009.00337.x

Cao, H. H. (1999). The Effect of Derivative Assets on Information Acquisition and Price Behavior in a Rational Expectations Equilibrium. Review of Financial Studies, 12(1), 131-163. http://doi.org/10.1093/rfs/12.1.131

Carhart, M. M. (1997). On Persistence in Mutual Fund Performance. The Journal of Finance, 52(1), 57-82. http://doi.org/10.1007/978-3-8349-6527-1_5

Chakravarty, S., Gulen, H., \& Mayhew, S. (2004). Informed trading in stock and option markets. The Journal of Finance, 59(3), 1235-1258. http://doi.org/10.1111/j.1540-6261.2004.00661.x

Chen, C. R., Lung, P. P., \& Tay, N. S. P. (2005). Information flow between the stock and option markets: Where do informed traders trade? Review of Financial Economics, 14(1), 1-23. http://doi.org/10.1016/j.rfe.2004.03.001

Conrad, J. (1989). The price effect of option introduction. The Journal of Finance, 44(2), 487-498. http://doi.org/10.2307/2328601

Cooper, M. J., Knott, A. M., \& Yang, W. (2015). Measuring Innovation (SSRN Scholarly Paper No. ID 2572815). Rochester, NY: Social Science Research Network. http://doi.org/ 10.1787/9789264059474-40-en

Ernst, C. (2012). Evaluation of Tax Incentives for Research and Development in Germany. BoD - Books on Demand. http://doi.org/10.1057/9780230513808_2

Fama, E. F., \& French, K. R. (1992). The Cross-Section of Expected Stock Returns. The Journal of Finance, 47(2), 427-465. http://doi.org/10.1111/j.1540-6261.1992.tb04398.x

Fama, E. F., \& French, K. R. (1993). Common risk factors in the returns on stocks and bonds. Journal of Financial Economics, 33(1), 3-56. http://doi.org/10.1016/0304-405X(93)90023-5 
Hall, B. H., Jaffe, A., \& Trajtenberg, M. (2005). Market value and patent citations. RAND Journal of Economics, 16-38. http://doi.org/10.2139/ssrn.1868847

Hirshleifer, D., Hsu, P. H., \& Li, D. (2013). Innovative efficiency and stock returns. Journal of Financial Economics, 107(3), 632-654. http://doi.org/10.2139/ssrn.1799675

Hu, J. (2014). Does option trading convey stock price information? Journal of Financial Economics, 111(3), 625-645. http://doi.org/10.1016/j.jfineco.2013.12.004

Jennings, R., \& Starks, L. (1986). Earnings Announcements, Stock Price Adjustment, and the Existence of Option Markets. The Journal of Finance, 41(1), 107-125. http://doi.org/10.1111/j.1540-6261.1986.tb04494.x

John, K., Koticha, A., Subrahmanyam, M. G., \& Narayanan, R. (2003). Margin Rules, Informed Trading in Derivatives, and Price Dynamics (SSRN Scholarly Paper No. ID 218749). Rochester, NY: Social Science Research Network. http://doi.org/10.2139/ssrn.424981

Kaul, G., Nimalendran, M., \& Zhang, D. (2004). Informed Trading and Option Spreads (SSRN Scholarly Paper No. ID 547462). Rochester, NY: Social Science Research Network. http://doi.org/10.2139/ssrn.547462

Knott, A. M. (2008). R\&D/returns causality: Absorptive capacity or organizational IQ. Management Science, 54(12), 2054-2067. http://doi.org/10.2139/ssrn.1470465

Knott, A. M., \& Vieregger, C. (2014). An Empirical Test of Endogenous Firm Growth (SSRN Scholarly Paper No. ID 2382885). Rochester, NY: Social Science Research Network. http://doi.org/10.2139/ssrn.2382885

Lev, B., \& Zarowin, P. (1999). The Boundaries of Financial Reporting and How to Extend Them (Digest Summary). Journal of Accounting Research, 37(2), 353-385. http://doi.org/10.2307/2491413

MacKenzie, R. (2005). Why biotech needs business. Buffalo Business, 13, 10-15.

Mayhew, S., Sarin, A., \& Shastri, K. (1995). The Allocation of Informed Trading Across Related Markets: An Analysis of the Impact of Changes in Equity-Option Margin Requirements. The Journal of Finance, 50(5), 1635-1653. http://doi.org/10.2307/2329329

Ni, S. X., Pan, J., \& Poteshman, A. M. (2008). Volatility Information Trading in the Option Market. The Journal of Finance, 63(3), 1059-1091. http://doi.org/10.1111/j.1540-6261.2008.01352.x

OECD. (2013). OECD Science, Technology and Industry Scoreboard 2013. Paris: Organisation for Economic Co-operation and Development. http://doi.org/10.1787/sti_scoreboard-2013-sum-ru

Pan, J., \& Poteshman, A. M. (2006). The Information in Option Volume for Future Stock Prices. Review of Financial Studies, 19(3), 871-908. http://doi.org/10.1093/rfs/hhj024

Patel, D., \& Ward, M. R. (2011). Using patent citation patterns to infer innovation market competition. Research Policy, 40(6), 886-894. http://doi.org/10.1016/j.respol.2011.03.006

Patelis, A. D. (1997). Stock Return Predictability and The Role of Monetary Policy. The Journal of Finance, 52(5), 1951-1972. http://doi.org/10.1111/j.1540-6261.1997.tb02747.x

Roll, R., Schwartz, E., \& Subrahmanyam, A. (2009). Options trading activity and firm valuation. Journal of Financial Economics, 94(3), 345-360. http://doi.org/10.1016/j.jfineco.2009.02.002

Scholes, M. S., Wolfson, M. A., Erickson, M., Maydew, E. L., \& Shevlin, T. (1992). Taxes and business strategy: A planning approach. Englewood Cliffs, NJ: Prentice Hall. http://doi.org/10.1057/jibs.1993.41

Sood, A., \& Tellis, G. J. (2009). Do innovations really pay off? Total stock market returns to innovation. Marketing Science, 28(3), 442-456. http://doi.org/10.1287/mksc.1080.0407

Sougiannis, T. (1994). The Accounting Based Valuation of Corporate R\&D. The Accounting Review, 69(1), 44-68.

Trajtenberg, M. (1990). A penny for your quotes: patent citations and the value of innovations. The Rand Journal of Economics, 172-187. http://doi.org/10.2307/2555502

Van der Eerden, C., \& Saelens, F. H. (1991). The use of science and technology indicators in strategic planning. Long Range Planning, 24(3), 18-25. http://doi.org/10.1016/0024-6301(91)90180-V 


\section{Appendix}

\section{Variable Definition}

\begin{tabular}{|c|c|}
\hline RQ & Research Quotient. Firm-specific output elasticity of R\&D (Knott, 2008) \\
\hline Firm fixed effect & Constant \\
\hline Capital & Net property, plant, and equipment \\
\hline Labor & Labor as full-time equivalent employees, in units of 1000 \\
\hline Lagged R\&D & Lag R\&D one year. Lag effect of past research investments on productivity \\
\hline Lagged spillovers & $\begin{array}{l}\text { Sum of differences in knowledge between focal firm } i \text { and rival firm } j \text { for all firms in the four digit SIC } \\
\text { industry with more knowledge (R\&D) than the focal firm }\end{array}$ \\
\hline \multicolumn{2}{|l|}{ Firm characteristics: } \\
\hline Total assets & Total book assets \\
\hline $\mathrm{BE}$ & $\begin{array}{l}\text { Book value of equity, calculated as stockholders' equity plus balance sheet deferred taxes and investment tax } \\
\text { credit, minus book value of preferred stock }\end{array}$ \\
\hline $\begin{array}{l}\text { Market-to-Book equity } \\
\text { (MTB) }\end{array}$ & $\begin{array}{l}\text { Market value of equity divided by Book value of equity for the fiscal year ending in calendar year t. Market } \\
\text { value of equity is calculated as number of shares outstanding times the share price at December of year t. }\end{array}$ \\
\hline $\begin{array}{l}\text { Book-to-Market equity } \\
\text { (MTB) }\end{array}$ & $\begin{array}{l}\text { Book value of equity divided by Market value of equity for the fiscal year ending in calendar year t. Market } \\
\text { value of equity is calculated as number of shares outstanding times the share price at December of year t. }\end{array}$ \\
\hline Revenue & Total revenue \\
\hline R\&D expense & Research and Development expenditures \\
\hline R\&D/ Assets & Research and Development expenditures scaled by Total book assets \\
\hline Advertising & Firm's advertising expense \\
\hline PPE/ Assets & property, plant and equipment scaled by Total book assets \\
\hline Capex/ Assets & Capital expenditure scaled by Total book assets \\
\hline $\mathrm{R} \& \mathrm{D} / \mathrm{BE}$ & Research and Development expenditures scaled by Total book equity \\
\hline Abnormal earnings & $\begin{array}{l}\left(E_{i, t}^{B}\left(1-\tau_{i, t}\right)-r_{t} B E_{i, t-1}\right) / B E_{i, t} \text {, where } E_{i, t}^{B} \text { is earnings after extraordinary items before expensing R\&D } \\
\text { expense and less preferred dividends from firm I in year } \mathrm{t}, \tau_{i, t} \text { is tax rate, and } r_{t} \text { is three months U.S. } \\
\text { Treasury Bill rate }\end{array}$ \\
\hline \multicolumn{2}{|l|}{ Others: } \\
\hline R\&D tax shield & R\&D expenditure multiplied by the tax rate, scaled by Book equity \\
\hline Asset growth & 1 year percentage change in Total firm assets \\
\hline BHRET6 & Compounded buy and hold returns of the prior six months returns from month $\mathrm{t}-7$ to $\mathrm{t}-2$ for month $\mathrm{t}$ \\
\hline
\end{tabular}

\section{Copyrights}

Copyright for this article is retained by the author(s), with first publication rights granted to the journal.

This is an open-access article distributed under the terms and conditions of the Creative Commons Attribution license (http://creativecommons.org/licenses/by/4.0/). 